\title{
Peertechz
}

\section{Reuse of industrial wastewater for agriculture area}

\author{
Abhishek Shehra* \\ Poornima College of Engineering, Civil Engineering, Jaipur, Rajasthan, 302022, India
}

Received: 26 July, 2021

Accepted: 10 August, 2021

Published: 11 August, 2021

*Corresponding author: Abhishek Shehra, Poornima College of Engineering, Civil Engineering, Jaipur, Rajasthan, 302022, India, Tel: +919079098168; E-mail: abhishekshehra222@gmail.com, 2017pceceabhishek004@poornima.org

ORCID: https://orcid.org/0000-0001-5990-802X

Keywords: B.O.D; C.O.D; Wastewater; Dilution factor; Treatment; Screening and sedimentation

https://www.peertechzpublications.com

\section{Abstract}

Now a days we see that a large amount of water has been wasted either in sewage or soil. it suffers from shortage of water supply for irrigation uses. On the other hand, the production system in the Rajasthan region is characterized by many agricultural food industries, the activity of which produces large amounts of wastewater. It is usually discharged into torrents or rivers. To manage this wastewater and also to fulfil the water demand in agriculture area thereby reduce the load on natural water stream, this wastewater should be used for various purposes including agriculture after with or without conventional or advanced treatment. In this project we took two sample of water then we conduct the test. Then analysis the result with irrigation till now we conduct (pH Test, Electrical Conductivity Test, Hardness Test, Alkalinity Test) and all results are good according to the I.S code \& I got success to find a new water sources for agricultural purpose.

\section{Purpose of the manuscript}

- The objective of this manuscript is to analyse the water quality of agro industry wastewater

- The most Common reasons for establishing a reuse program is to identify new water source.

Subject: Environmental Pollution.

\section{Introduction}

In recent years, the continuous growth of world population along, the intensification of industrial and agricultural events for increasing food supply and the more and more continued droughts, have caused the consumption of existing water resources until reaching their maximum amount in arid and semi-arid regions. Therefore, any sources of water which could be used economically and effectively should be considered to market further growth. In regions with limited natural water sources, treated wastewater including agro industrial one must be taken into account for agricultural and industrial use [1-5].

In northwest region of India as a semi-arid area, suffers from shortages of water supply for agricultural uses. On the other hand, the manufacture system of this region is characterized by numerous agro-food industries, whose activity manufactures large amounts of wastewater usually discharged into torrents or rivers. In this contest, a careful management of agro-industrial wastewater for agricultural use, after a indispensable treatment, represents a useful alternative to conventional water resources. It is worth treating wastewater for recycling because agriculture uses large amounts of water - $70 \%$ of the world's freshwater is used for agriculture and groundwater in underground rivers is drained much faster than natural processes. Surface situation is no longer the best so it is also benefits farmers as the cost of treating and using wastewater is lower compared to river disposal (direct cost with storage or transportation of river disposal, US \$ $0.40 / \mathrm{m} \mathrm{3}$, cost of irrigation US $\$ 0.28 / \mathrm{m} 3$ or, including the value of nutrients in wastewater is US $\$ 0.22$ / $\mathrm{m} 3$; therefore, agricultural recycling directly saves US $\$ 0.40-0.22=$ US $\$$ 0.18 / m 3 Money [2].

\section{Methods}

There are two methods of sewage disposal by utilizing natural agencies [5-8]. 


\section{Sample collection}

Analyze result

with standards

\section{Test of row} water

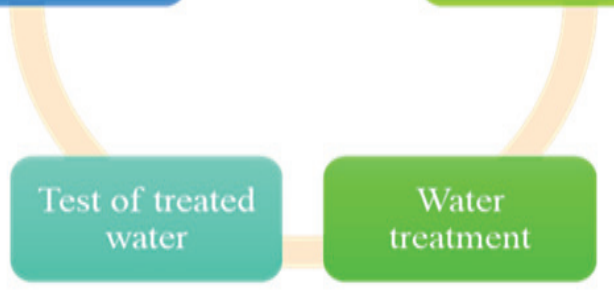

\section{Step-1 : collection of sample}

Wastewater sample is collected from the agro industry.

\section{Step-2 : treatment of wastewater}

The "Jaipur City" produces on average about 20 MLD of wastewater, which is mainly composed of process water (Fruit processing and cleaning), water from the bottles and washing line. The operation of wastewater treatment plant, in the following steps: primary treatment (screening, oil removal, equalization and $\mathrm{pH}$ adjustment); secondary treatment - SW - (activated sludge process - anoxic plus aerobic phases and chemically assisted secondary sedimentation); tertiary treatment (sand filtration, membrane ultrafiltration.

\section{Step-3 : Materials procurement for test}

Sodium carbonate, Standard Sulphuric acid, Phenolphthalein and Methyl orange indicator, Methyl red, EDTA) and apparatus (ph meter, electrical conductivity apparatus) ,Burette, pipette, Conical flask, Beakers, Burette stand and Clamp to conduct test.

\section{Step-4 : Test performed}

1. $\mathrm{pH}$ Test

2. Electrical Conductivity for known salt concentration.

3. Hardness test

4. Alkalinity of water

5. Chloride Concertation

6. S.A.R

7. Boron Concertation.

\section{Step-5 : Analysis}

> Compare the results with the Indian standard code IS 11624 (1986) to check treated wastewater's properties.

> Check water quality is pass or fail for irrigation if the treated wastewater can't fill the criteria for irrigation, then check the other area for used the water.

\section{Results and discussion}

According to chart the ph value of un -treated sample is 6.23 then we get 7.23 value of treated water, so it is good for plant because soil ph regulates the availability of plant nutrients by regulating the chemical composition of various nutrients and also influencing their chemical activity Table 1.

We get 750 micromhos/cm electrical conductivity of sample and it is good for plant because the water has low salinity and low salinity good for production in crops.

$>$ According to the result the total alkalinity $\left(\mathrm{CaCO}_{3}\right)$ of Sample is 12 but the according to the research it is ideal for irrigation.

$>$ According to the result quality $(5 \mathrm{me} \mathrm{L-1)}$ of water is good for irrigation so plants will be good in growth.

$>$ According to the result quantity of chloride is $7 \mathrm{me} / \mathrm{L}$ so this type water is good for all crops.

$>$ When sodium value is good then it is involved in electrical neutralization of inorganic and organic anions and macromolecules, $\mathrm{pH}$ homeostasis, control of membranefelectrical potential, and the regulation of cell osmotic pressure.

\section{Water replace data}

According to our survey we found that about 5MLD wastewater (Agro industry) is going in river or Channel. This is a golden opportunity for save water. According to paper we got that total $500 \mathrm{~mm}$ of water is required for kharif crops (4 TIMES) and $250 \mathrm{~mm}$ of water is required for rabi crops so we can easily replace $60 \%$ water amount from fresh water in rabi crops and $40 \%$ in kharif crops. From this way we can easily remove load from fresh supply.

$>$ Through this investigation, our test proved helpful even though they were done on a small scale. If we adopted this process, then it will drastically reduce the water stress by replacing the wastewater with row water.

Table 1: Water quality with standards.

\begin{tabular}{|c|c|c|}
\hline Test Name & Result Before Treatment & Result After Treatment \\
\hline pH Test & 6.23 & 7.23 \\
\hline Electrical Conductivity & 1970 micromhos/cm & 750 micromhos/cm \\
\hline Hardness test & $166 \mathrm{mg} / \mathrm{l}$ & $81 \mathrm{mg} / \mathrm{l}$ \\
\hline Alkalinity of water & $10 \mathrm{mg} / \mathrm{l} \& 2 \mathrm{mg} / \mathrm{l}$ & 0 \\
\hline Chloride Concertation & 7 & 5 \\
\hline S.A.R & 10.33 & 7 \\
\hline Boron Concertation & 3 & .45 \\
\hline
\end{tabular}

\section{References}

1. Al-Jasser AO (2011) Saudi wastewater reuse standards for agricultural irrigation: Riyadh treatment plants effluent compliance. Journal of King Saud University - Engineering Sciences 23: 1-8. Link: https://bit.ly/2VChb1D 
2. Haruvy N (1997) Agricultural reuse of wastewater: nation-wide cost-benefit anlysisis. Journal of Agriculture, Ecosystems and Environment 66: 113-119. Link: https://bit.ly/3AzfcKg

3. Tarantino E, Disciglio G, Gatta G, Libutti A, Frabboni L, et al. (2017) Agroindustrial Treated Wastewater Reuse for Crop Irrigation: Implication in soil Fertility. Journal of The Italian Association of Chemical Engineering 58. Link: https://bit.ly/2Vlhs2K

4. Rajinikanth R, Saady N, Torrijos M, Thanikal J, Hung YT (2013) Sustainable Agro-Food Industrial Wastewater Treatment Using High Rate Anaerobic Process. Journal of Water 5. Link: https://bit.ly/3CDxCLG

5. Alayu E, Yirgu Z(2018) Advanced technologies for the treatment of wastewaters from agro-processing industries and cogeneration of by-products: a case of slaughterhouse, dairy and beverage industries. Int J Environ Sci Technol 15: 1581-1596. Link: https://bit.ly/3jl78zT

6. Chauhan HS (1987) Guideline for the quality of irrigation water. Indian Standard. Link: https://bit.ly/3AyAk3m

7. Lazarova V, Bahri A (2004) Water reuse for irrigation agriculture, landscapes, and turf grass. Crc Press, Tunisia. Link: https://bit.ly/3izO8V2

8. Rautray A (2010) Waste water reuse in agriculture: From Waste water use ito water reclamation: management and challenge, LAP Lambert Academic Publishing, India

\section{Discover a bigger Impact and Visibility of your article publication with} Peertechz Publications

\section{Highlights}

* Signatory publisher of ORCID

* Signatory Publisher of DORA (San Francisco Declaration on Research Assessment)

* Articles archived in worlds' renowned service providers such as Portico, CNKI, AGRIS, TDNet, Base (Bielefeld University Library), CrossRef, Scilit, J-Gate etc.

* Journals indexed in ICMJE, SHERPA/ROMEO, Google Scholar etc.

* OAI-PMH (Open Archives Initiative Protocol for Metadata Harvesting)

* Dedicated Editorial Board for every journa

* Accurate and rapid peer-review process

* Increased citations of published articles through promotions

* Reduced timeline for article publication

Submit your articles and experience a new surge in publication services (https://www.peertechz.com/submission).

Peertechz journals wishes everlasting success in your every endeavours.

Copyright: ( 2021 Shehra A. This is an open-access article distributed under the terms of the Creative Commons Attribution License, which permits unrestricted use, distribution, and reproduction in any medium, provided the original author and source are credited. 